Matematikai Közlemények

V. kötet, 2017

doi:10.20312/dim.2017.02

\title{
Négydimenziós konvex politóp ábrázolása GeoGebrával
}

\author{
Talata István \\ Szent István Egyetem, \\ Ybl Miklós Építéstudományi Kar, Budapest, \\ és Dunaújvárosi Egyetem, Dunaújváros \\ talata.istvan@ybl.szie.hu
}

\begin{abstract}
ÖSSZEFOGLALÓ. Bemutatjuk, hogy a GeoGebra dinamikus geometriai szoftverrel hogyan lehet ábrázolni egy 4-dimenziós konvex politópot a 3-dimenziós euklideszi térben centrális vetületként, majd összegezzük a szerzőnek a témakörrel kapcsolatos oktatási tapasztalatait.

ABSTRACT. We demonstrate how one can visualize a 4-dimensional convex polytope with GeoGebra, represented by its central projection in the 3-dimensional Euclidean space. Then we sum up the educational experiences of the author in this subject.
\end{abstract}

\section{Bevezetés}

Megmutatjuk, hogyan tudunk szemléltetni egy adott 4-dimenziós konvex politópot annak 3-dimenziós térre történő centrális vetületeivel, melyek 3-dimenziós poliédercellákból állnak. A politóp modellezéséhez és a 3-dimenziós vetületének az ábrázolásához a GeoGebra dinamikus geometriai szoftvert használjuk (ld. [3]).

A 3-dimenzióban centrális vetületként történő ábrázolás azért kézenfekvő, mert az emberi látásnak megfelelő centrális projekció (amely a 3-dimenziós térben egy síkra történő középpontos vetítéssel biztosít perspektív nézetet) 4-dimenziós térbeli analogonja egy 3-dimenziós affin altérre (vetítőhipersíkra) történő centrális projekció, és ez az altér azonosítható a 3-dimenziós euklideszi térrel (ld. [1], [4], [5] hivatkozásokat a 4D alakzatok 3D-ben történő szemléltetése témakörben).

Mivel a dimenziócsökkenéssel információvesztés jár együtt, ezért az alkalmazott centrális vetítést többféle nézőpontból, a centrum és vetítőhipersík együttes megváltoztatásával is célszerü elvégezni (akár folytonos keringést végezve), amely müvelet felfogható úgy is, hogy a centrum és a vetítőhipersík (valamint egy hozzájuk tartozó koordináta-rendszer) fix, és a 4-dimenziós konvex politóp mozog, ill. változtatja méretét (eltolás, forgatás és középpontos nyújtás alkalmazásainak hatására).

A SZIE Ybl Miklós Építéstudományi Karon a „Matematika és geometria az építészetben” választható tárgy keretein belül foglalkoztunk ezzel a problémával, mert ezen izgalmas, emberi fantáziát megmozgató témakör kapcsán a geometriai transzformációk matematikai elméletébe is mélyebb betekintést tudtunk nyújtani a hallgatóknak. (Így a síkbeli és háromdimenziós térbeli számításokkal teljesen analóg módon lehetett megadni a forgatás és

KULCSSZAVAK. Szabályos test, konvex politóp, transzformáció mátrix, láthatóság, dinamikus geometria, GeoGebra.

KEYWORDS. Regular solid, convex polytope, transformation matrix, visibility, dynamic geometry, GeoGebra. 
vetítés eredményét a 4-dimenziós térben, ahol már a szokásos ábrázolási módszerek nem lehetségesek.) Továbbá a transzformációk hatását vetületek segítségével is tudtuk láttatni a hallgatók számára úgy, hogy érdekes háromdimenziós alakzatok ábrázolására vezetett ez a feladat.

\section{Konvex politópok}

Egy $d$-dimenziós konvex politópon (ahol $d \geq 1$ egész szám) a $d$-dimenziós euklideszi tér véges sok zárt félterének a metszetét értjük, ha az egy nemüres belsejű korlátos részhalmaza a térnek. Megmutatható, hogy ezzel ekvivalens véges sok, nem egy közös hipersíkban elhelyezkedő pont konvex burkaként definiálni a konvex politópot. Egy $d$-dimenziós konvex politóp beágyazható egy $d$-nél magasabb dimenziós euklideszi térbe, ha annak egy $d$-dimenziós affin alterének a részhalmazaként van megadva. A politóp határán $k$-dimenziós lapok helyezkednek el $(0 \leq k \leq d-1)$, és $k=0,1,2,3, d-1$ esetén ezeket csúcsoknak, éleknek, 2D-lapoknak, 3D-lapoknak, ill. hiperlapoknak nevezzük (tehát $d=4$ esetén a hiperlapok a 3D-lapok). A csúcsok konvex burka kiadja a konvex politópot, a hiperlapok uniója kiadja a politóp határát, a hiperlapok egy cellarendszert $((d-1)$-dimenziós konvex politópokat) határoznak meg, egymáshoz $(d-2)$-dimenziós lapjaikkal csatlakozó elemekkel (ld. [6]).

A 3-dimenziós euklideszi térben a konvex politópot konvex poliédernek hívjuk. A $d$-dimenziós konvex politópokat röviden konvex $d$-politópoknak is nevezzük.

A 4-dimenziós konvex politópok közül az egyik legnevezetesebb osztály a szabályos konvex 4-politópoké. Ezt az a 6 politóp alkotja, amely a 3-dimenziós szabályos poliéderekkel analóg módon szabályos hiperlapokkal rendelkezik, és a csúcsalakzata is szabályos, azaz bármely csúcsához közel elmetszhető egy olyan hipersíkkal a politóp, mellyel a metszete egy szabályos 3-dimenziós poliéder, és az annak a középpontján átmenő és a hipersíkra merőleges egyenes áthalad a csúcson is. (Ezzel a metszet szimmetriái a csúcsalakzat és egyben az egész politóp szimmetriáivá is kiterjeszthetők.)

A szabályos konvex 4-politópok: 4-szimplex (5-cella, a tetraéder analogonja), 4-keresztpolitóp (8-cella, az oktaéder analogonja), 4-kocka (16-cella, a kocka analogonja), 24-cella (nem analogonja egyik háromdimenziós szabályos poliédernek sem, azonban a rombikus dodekaéder analogonja, amely 3-dimenzióban nem szabályos test), 120-cella (a dodekaéder analogonja), és a 600-cella (az ikozaéder analogonja), ld. [2]. A cellák száma az elnevezésekben a hiperlapok számát adja meg. A 120-cellának már 600 csúcsa és 1200 éle van, a 600 cellának pedig 720 éle és 1200 2D-lapja van, ezért ezeknek elég nehézkes a szemléltetése. Emiatt ez utóbbi politópoknak gyakran csupán a hiperlapjaik egyes csoportjait (melyek bizonyos értelemben összetartozó elemekből állnak) szokás egyszerre ábrázolni (3-dimenziós vetületeikkel szemléltetve azokat), hogy még felismerhetők legyenek az egyes ábrázolt alakzatok.

\section{Modellezés és szemléltetés GeoGebrával}

A következőkben leírjuk a 4-dimenziós politópok GeoGebrában történő modellezésének és ábrázolásának a lépéseit, ahogy azt megvalósítottuk a SZIE Ybl Miklós Építéstudományi Karon a „Matematika és geometria az építészetben” választható tárgy keretein belül.

Az adott kurzuson a 4-dimenziós kockát készítettük el ilyen módon, a hallgatók házi feladatként hasonló módon elkészítettek egy-egy másik szabályos konvex 4-politópot (a 4-keresztpolitópot, ill. a 24-cellát). 


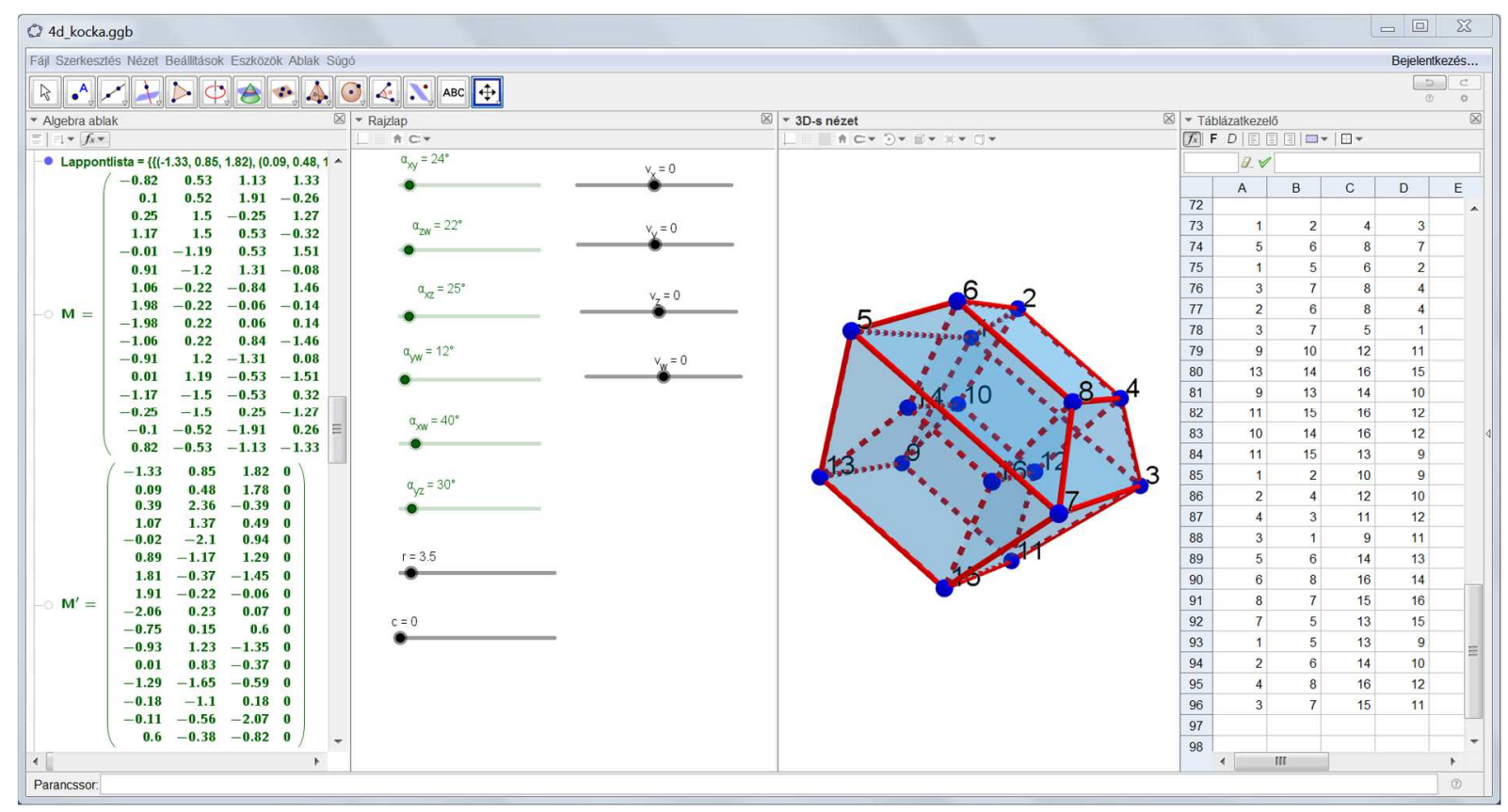

1. ábra. A modellezés GeoGebra munkalapja

Az itt leírt módszer tetszőleges konvex 4-politóp ábrázolására használható, ennek csupán az lehet a gátja, ha a politóp olyan sok elemből áll, hogy azt már a szoftver (jelen esetben a GeoGebra) nem tudja kezelni.

\subsection{Csúcsok megadása}

Először felvisszük a csúcsok koordinátáit, $n$ csúcs esetén egy $n \times 4$-es mátrixba, amelyben az egyes sorok tartalmazzák egy-egy csúcs koordinátáit a 4-dimenziós térben. Azért nem a szokásos oszlopvektor megadást választottuk az egyes csúcsokra, mert sorvektorok esetén jobban látható a mátrix a bal oldalon elhelyezkedő Algebra ablakban.

Ha a Táblázatkezelő celláiba gépeljük be a 4-kocka csúcsait, pl. az összes \pm 1 értékü koordinátát tartalmazó koordináta-négyesekként, akkor a 16 csúcs miatt $16 \times 4$-es tömböt kapunk. Ezután kijelölve a cellákat, jobb egérgombbal klikkelve, kiválasztható a Létrehozás $\rightarrow$ Mátrix opció, végül az elkészült mátrix átnevezhető egy kívánt (pl. $\left.M_{0}\right)$ névre.

\subsection{Csúcstranszformáció}

Eltolás és forgatás együttes alkalmazásával valósítjuk meg a csúcspontok tetszőleges mozgatását.

A 4-dimenziós térben 2-dimenziós affin alterek körül lehet forgatni. Az összes 2-dimenziós koordinátasíkra elkészítünk egy-egy forgatási mátrixot (a rájuk merőleges 2-dimenziós koordinátasíkok pontjai a forgatás fixpontjai): $(x, y, z, w)$ változókat használva az egyes koordinátákra, az $F_{x y}, F_{z w}, F_{x z}, F_{y w}, F_{x w}, F_{y z}$ forgatási mátrixok $F$ szorzatmátrixa az alkalmazott forgatások együttes hatására keletkező forgatás mátrixa. Például az $F_{x y}$ így adható meg (az $\alpha_{x y}$ szöget úgy adjuk meg, hogy értéke egy csúszkán állítható legyen):

$$
F_{x y}=\left(\begin{array}{cccc}
\cos \left(\alpha_{x y}\right) & -\sin \left(\alpha_{x y}\right) & 0 & 0 \\
\sin \left(\alpha_{x y}\right) & \cos \left(\alpha_{x y}\right) & 0 & 0 \\
0 & 0 & 1 & 0 \\
0 & 0 & 0 & 1
\end{array}\right)
$$


A többi forgatási mátrix is hasonlóan adható meg, csak esetükben értelemszerủen nem az első két koordinátában történik a forgatás, hanem másik koordinátapár alkalmazásával. Így összesen 6 forgatási szög állítható be csúszkán. Kevesebb forgatási szög is elégséges lenne ahhoz, hogy egy tetszőleges forgatást létrehozzunk, de előnyös az összes 2D-koordinátasíkon történő forgatás lehetőségét meghagyni a szemléltetéshez.

Egy $v$ eltolásvektor alkalmazásával (melynek koordinátái mind állíthatók csúszkán) az $M_{0}$ mátrix minden sorára az $x_{1}=x+v$ képlettel kiszámítjuk az eltoltját (így keletkezik az $M_{1}$ mátrix), majd az $M=M_{1} \cdot F^{T}$ transzponált mátrixot tartalmazó mátrixszorzás után megkapjuk az eltolt, majd forgatott csúcsok $M$ mátrixát.

Nyújtást nem alkalmazunk (amely a zoomolásnak felelne volna meg), ennek hatását a vetítőhipersík helyzetének a megváltoztatásával (párhuzamos eltolásával) tudjuk majd imitálni (ld. a modellezés következő lépését).

\subsection{Centrális projekció}

Egy paramétertől függő vetítési centrumot hozunk létre a $K(0,0,0, r) \in \mathbf{R}^{4}$ pontban, a vetítési hipersíknak pedig a $w=-c$ egyenlethez tartozó hipersíkot vesszük fel $(r>0, c \geq 0$ csúszkán állítható paraméterek).

A vetítőhipersíkra történő centrális projekció képlete egyszerüen kiszámítható. Ha egy $\mathbf{x} \in \mathbf{R}^{4}$ helyvektorú pont vetülete az $\mathbf{y} \in \mathbf{R}^{4}$ helyvektorú pont, melyre így az $\langle\mathbf{n}, \mathbf{y}\rangle=a$ egyenlet teljesül (amely azt fejezi ki, hogy $\mathbf{y}$ végpontja a vetítőhipersík egy pontja), ahol $\mathbf{n} \in \mathbf{R}^{4}$ a vetítési hipersík normálvektora, $\langle$, $\rangle$ skalárszorzatot jelöl, $a \in \mathbf{R}$, és $\mathbf{k} \in \mathbf{R}^{4}$ a centrális projekció középpontjának helyvektora, akkor azt keressük, hogy hol található $\mathbf{y}$ végpontja az $\mathbf{x}$ és $\mathbf{k}$ helyvektorú pontok által meghatározott egyenesen, azaz felírható $\mathbf{y}=t \mathbf{x}+(1-t) \mathbf{k}$ alakban, és keressük az ebben szereplö $t \in \mathbf{R}$ paraméter értékét. Ez a következőképp tehető meg:

$$
\begin{gathered}
\mathbf{y}=t \mathbf{x}+(1-t) \mathbf{k}=\mathbf{k}+t(\mathbf{x}-\mathbf{k}), \quad\langle\mathbf{n}, \mathbf{y}\rangle=a, \\
\langle\mathbf{n}, \mathbf{k}+t(\mathbf{x}-\mathbf{k})\rangle=a, \\
\langle\mathbf{n}, \mathbf{k}\rangle+t\langle\mathbf{n}, \mathbf{x}-\mathbf{k}\rangle=a, \\
t=\frac{a-\langle\mathbf{n}, \mathbf{k}\rangle}{\langle\mathbf{n}, \mathbf{x}\rangle-\langle\mathbf{n}, \mathbf{k}\rangle}
\end{gathered}
$$

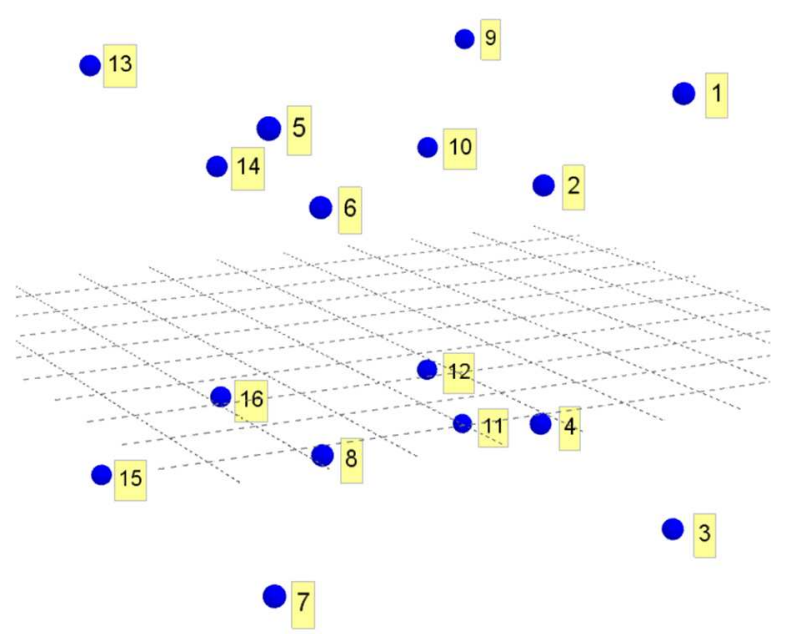

2. ábra. A csúcsok vetülete az indexfelirataikkal 
Jelen esetben $\mathbf{n}=(0,0,0,1), \mathbf{k}=(0,0,0, r), a=-c$, ezért

$$
t=\frac{-c-r}{\mathbf{x}_{4}-r}
$$

ahol $\mathbf{x}_{4}$ a 4-edik, $w$ koordinátája az $\mathbf{x}$ vektornak. Az így kiszámított vetítést alkalmazzuk az összes transzformált csúcsra, azaz az $M$ mátrix minden sorára. A vetítés után kapott $M^{\prime}$ mátrix soraiban a 4-edik koordináták mind $-c$-vel egyenlök, azokat elhagyva egy $n \times 3$-as $N$ mátrix készíthető, amelyből a

\section{Pontlista $=\operatorname{Sorozat}(\operatorname{Pont}($ Elem $(\mathrm{N}, \mathrm{i})), \mathrm{i}, \mathrm{1}, \mathrm{n})$}

paranccsal egy pontlista készíthető, ez ábrázolásra kerül a GeoGebra 3D-s nézet ablakában.

Az élek, majd később a lapok vetületének az elkészítéséhez segítséget nyújthat, ha látjuk az egyes csúcsok sorszámait (indexeit). Ehhez létrehozzunk egy feliratlistát:

Feliratlista=Sorozat(Szöveg(i, Elem(Pontlista, i) $+(0.1,0,0))$, i, 1, n)

Azért szerepel a fenti parancsban egy $(0.1,0,0)$ vektorral történő eltolás, hogy a felirat ne lógjon bele a csúcsot reprezentáló kis gömbbe.

\section{4. Élek vetülete}

A Táblázatkezelőben felvisszük az élek indexeinek listáját, ez egy $n_{1} \times 2$-es tömb azon $(i, j)$ indexpárokkal $(1 \leq i<j \leq n)$, melyekre az $i$-edik és a $j$-edik csúcs (azaz az $M i$-edik és $j$-edik sorához tartozó csúcsok) éllel vannak összekötve. Ebből készítünk egy $n_{1} \times 2$-es élmátrixot. A 4-kocka esetén ez egy $32 \times 2$-es mátrix.
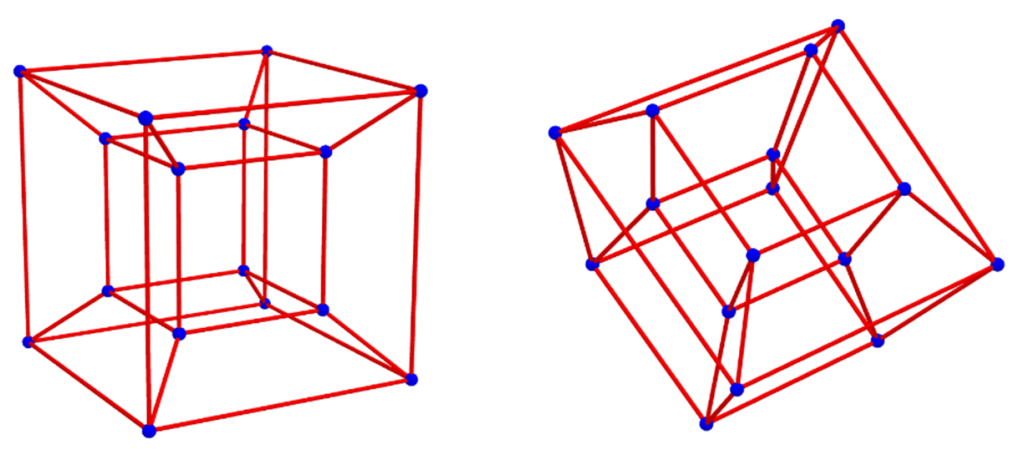

3. ábra. Élek ábrázolása különböző nézetekben

Majd készítünk egy éllistát a csúcsok vetületeit összekötő szakaszokból az élekhez tartozó csúcspárok esetén:

\section{Ellista=Sorozat(Szakasz(Elem(Pontlista, Elem(Elmatix, i, 1)), Elem(Pontlista, Elem(Elmatrix, i, 2))), i, 1, n_1)}

\subsection{Lapok vetüllete}

A Táblázatkezelőben felvisszük a lapok indexeinek listáját, ez egy $n_{2} \times k_{2}$-es tömb azon indexekkel egy sorban, amelyekhez tartozó csúcsok egy 2-dimenziós lapon vannak, a megadás sorrendjében egymás után következve a sokszöglap határán ( $k_{2}$ a 2D-lapok csúcsszámainak maximuma, és olyan lapok esetében, ahol kisebb a csúcsszám ennél, ott nullákkal pótoljuk ki a tömb érintett sorát). Ebből egy $n_{2} \times k_{2}$-es 2 D-lapmátrixot készítünk Lapmatrix néven. A 4-kocka esetén ez egy $24 \times 4$-es mátrix. 
Majd egy laplistát készítünk a csúcsok vetületeire illeszkedő sokszögekből a 2D-lapokhoz tartozó csúcsok esetén úgy, hogy először egy Lappontlista listában felsoroljuk egy 2D-lap vetületének a csúcsait, majd ezekhez készítjük el a sokszögeket 3-dimenzióban:

- Lappontlista=Sorozat(Sorozat(Elem(Pontlista, Elem(Lapmatrix, i, j)), j, 1, k_2), $\mathrm{i}, 1, \mathrm{n} \_2$ )

- Laplista=Sorozat(Sokszög(Elem(Lappontlista, i) ), i, 1, n_2)

Az elöbbi parancsok közül a Lappontlista megadási parancsa akkor müködik jól, ha minden 2D-lap pontosan $k_{2}$ csúccsal rendelkezik - ha nem ez a helyzet, akkor kicsit módosítani kell a parancson, a Lapmatrix i-edik sorából csak a nem nulla értékekre végeztetve el a számítást.
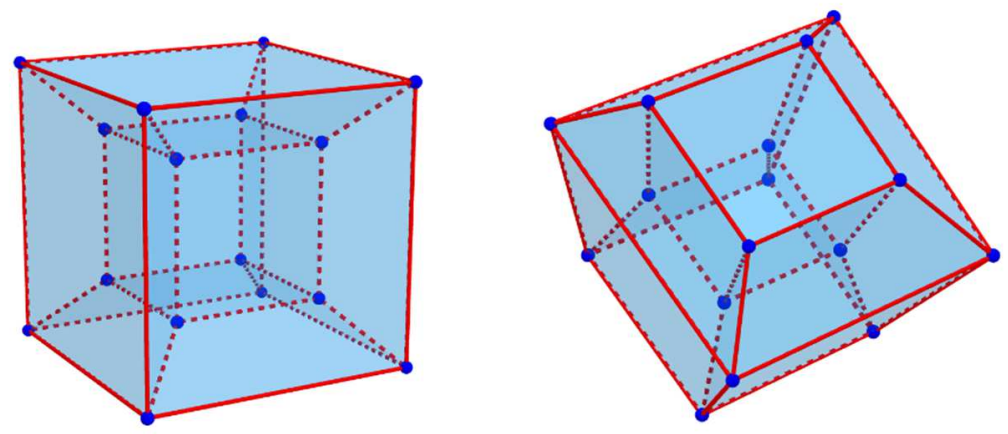

4. ábra. Lapok megjelenítése különböző nézetekben

\section{További lehetőségek GeoGebrával}

A következőkben felsorolunk néhány, a fentebb leírt modellben még nem megvalósult ábrázolási, ill. modellezési lehetőséget, melyekkel továbbfejlesztve a modellt, még szemléletesebbé tehető az ábrázolás, vagy egyszerübbé tehető a modellkészítés.

\subsection{Vetületi kép korrekciója}

A kapott 3-dimenziós vetület csak akkor helyes, ha nincs olyan csúcs, melynek a $Z$ koordinátája $r$-nél nagyobb, ugyanis ilyen esetben annak a csúcsnak nem létezik vetülete a vetítő hipersíkra, mert a vetítősugár félegyenese nem metszi azt a hipersíkot. Mivel a modell az egész vetítőegyenesnek a vetítőhipersíkkal vett metszéspontját számítja ki, így ilyen esetben kapunk egy fals csúcsvetületet, és az abba a csúcsba futó élek, ill. a csúcsra illeszkedő sokszögek vetületei sem lesznek helyesek. Az érintett élek helyett félegyeneseket kellene berajzolni, mert az élek vetülete ilyenkor nem korlátos. Az érintett 2D-lapok helyett pedig síkbeli nem korlátos konvex sokszögtartományokat kellene berajzolni. Ha nem konvex a 3D vetületi kép, akkor tudhatjuk, hogy ezzel a problémás esettel állunk szemben, ekkor állítsuk $r$ értékét megfelelően nagyra.

\subsection{Láthatóság}

A láthatóság nem került megoldásra ebben a modellben, így a hiperlapok vetületeinek cellái kétszeresen fedik le a vetület konvex burkát, a látható (azaz a vetítősugáron a centrumhoz közelebbi pontokat tartalmazó hiperlapok vetületcellái) és a nem látható (azaz a vetítősugáron a centrumtól távolabbi pontokat tartalmazó hiperlapok vetületcellái) részek mind ábrázolásra kerülnek. Azonban konvex $d$-politóp hiperlapjainak a normálvektorait ismerve könnyen eldönthető a láthatóság. Ugyanis akkor és csak akkor látható egy konvex $d$-politópnak egy hiperlapja, ha a vetítés centruma a hiperlap által kifeszített hipersíknak a 
politópot nem tartalmazó nyílt félterében helyezkedik el. A vetítési centrum helyvektorának a hipersík normálvektorával vett skalárszorzatával mindez könnyen leellenőrizhető, mint ahogy az is, hogy mely élek és 2D-lapok fekszenek egy 3D-lapon, ennek eldöntéséhez elég a 3D-lap normálvektorának a skaláris szorzatát kiszámítani az él vagy 2D-lap egy tetszőleges relatív belső pontjával (pl. a csúcsaik súlypontjával).

\subsection{Tetszőleges 2-dimenziós sík körülli forgatás}

A 4-dimenziós térben tetszőlegesen beállítható, de fix 2-dimenziós sík körüli forgatás megvalósítása hiányzik a modellből, csupán speciális irányú forgatások egyszerre történő alkalmazásával jön ki általános irányú forgatás. Érdemes lehet ilyen fogatást is megvalósítani.

\subsection{Konvex burok laphálójának kiszámítása}

A csúcsok megadása már meghatározza a konvex burok lapstruktúráját, de sajnos a GeoGebra nem teszi lehetővé ennek a lapstruktúrának a kiszámítását általános esetben, mivel ez a szoftver inkább ábrázolásra alkalmas, nagyobb mennyiségü számítás elvégzésére már nem. Szerencsére, ha már ismert a lapstruktúra, vagy más módon ki tudjuk azt számítani, akkor az élek, 2D-lapok és akár a 3D-lapok illeszkedései is felvihetők GeoGebrába (a 3D-lapokat azért nem vittük fel a 4-dimenziós modellbe az ábrázoláskor, mert azok vetületeit közvetlenül úgysem lehet ábrázolni, hanem csak a 2D-lapjaikat, ill. éleiket). Mindenesetre jó lenne, ha a csúcsok koordinátáin túlmenően minél kevesebb adat bevitele lenne szükséges a modell számára.

\section{Oktatási tapasztalat}

A SZIE Ybl Miklós Építéstudományi Karon a „Matematika és geometria az építészetben” választható tárgy keretein belül foglalkoztunk ezzel a témakörrel.

A CAD programok és egyéb 3D grafikai programok használatával a hallgatók elkényelmesedtek, mivel a 3D transzformációk (forgatás, tükrözés, nyújtás, eltolás), és a 3D keringés is kényelmesen, közvetlenül megvalósíthatók az ilyen programokban. Nincs igényük a mögöttes matematikai müveletek megismerésére.

Azért, hogy a geometriai transzformációk matematikájába jobb betekintést nyújtsunk a hallgatóknak, és a számukra is érdekes témakörrel tegyük ezt, elvégeztük a 4-dimenziós terek egy alakzatának (4-dimenziós kocka) a 3-dimenziós térre való centrális projekcióját, az alakzat forgatását, eltolását lehetővé téve szemléltetéskor.
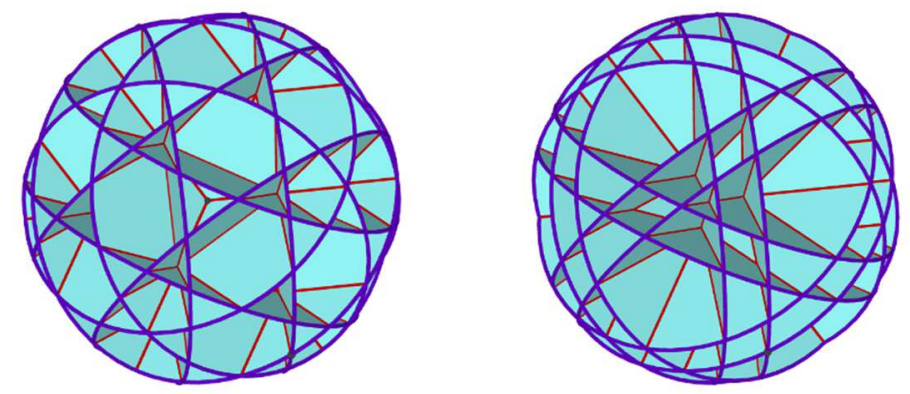

5. ábra. Szabályos dodekaéder lapsíkjai térfelosztásának az ábrázolása lapsíkokba rajzolt körlapokkal, különböző sugárméretek esetén 
A láthatóság megvalósítására már nem jutott idő ebben az esetben. Azonban 3D konvex szabályos, ill. archimédeszi poliéderekre kaptak olyan feladatot a hallgatók, hogy vizsgálják meg, hogy a poliédernek milyen laphalmazai láthatók egyszerre centrális vetületként - ez attól függ, hogy a lapok síkjainak melyik oldalán helyezkedik el a vetítési centrum, tehát a lapsíkok általi térfelosztást vizsgálták a hallgatók több-kevesebb sikerrel, de nagy lelkesedéssel.

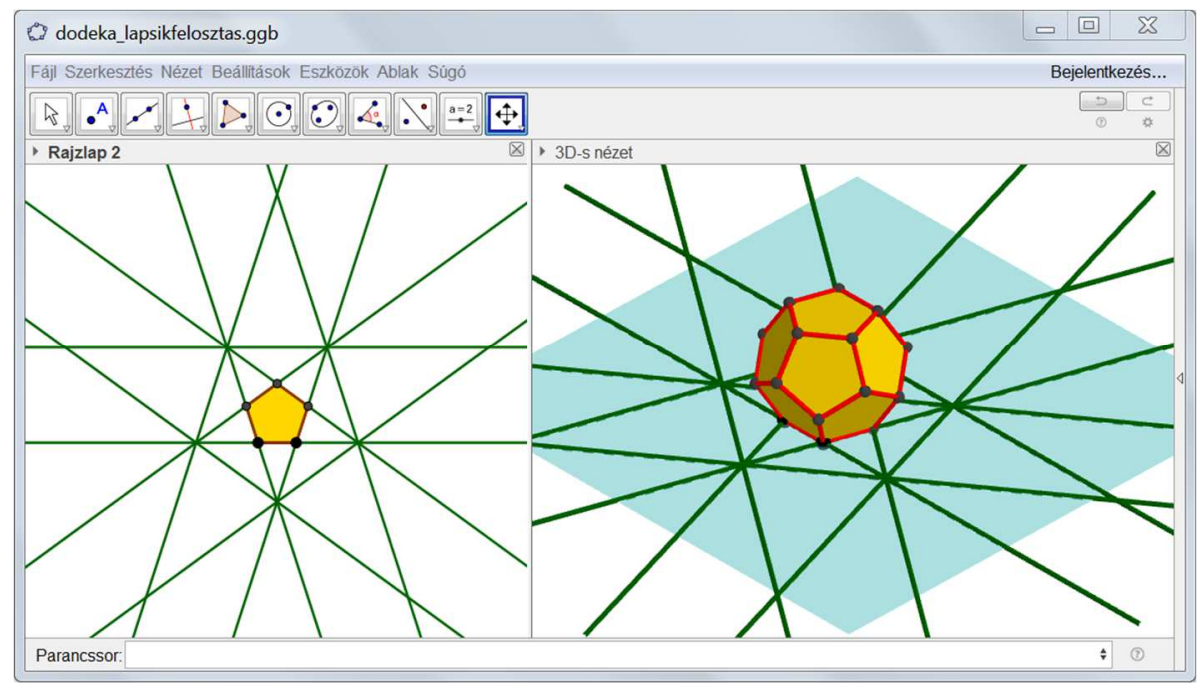

6. ábra. Szabályos dodekaéder lapsíkjai térfelosztásának az ábrázolása az egy lapsíkba metsző többi lapsík egyenesmetszeteivel

\section{Köszönetnyilvánítás}

Szeretném megköszönni Németh Lászlónak, hogy erröl a témakörről előadhattam Sopronban a Matematika Oktatása és Kutatása Szeminárium (MOKUS) 2017-es programjában.

\section{Irodalomjegyzék}

[1] 4D Visualization, http://eusebeia.dyndns.org/4d/vis/vis.

[2] Coxeter, H. S. M., Regular complex polytopes, Cambridge University Press (1991), pp. 210. ISBN 05213949-0-2.

[3] GeoGebra, https://www.geogebra.org/.

[4] Gévay, G., Miyazaki, K., Négydimenziós téridomok szemléltetése (Visualizing 4-dimensional geometric shapes), VII. Multimédia az oktatásban konferencia, Zrínyi Miklós Nemzetvédelmi Egyetem, Budapest, 2001. Konferenciakiadvány, http://www.mmo.njszt.hu/Kiadvanyok/2001/index_2001.htm (2001), 1-6.

[5] Kolcun, A., 3D visibility of 4D Convex Polyhedra. In: WSCG'2005 Poster Proceedings. Plzeň: Západočeská univerzita, 2005. Západočeská univerzita (2005), 35-36. ISBN 80-903100-8-7.

[6] Szabó L., Konvex geometria, Egyetemi jegyzet, ELTE (1996) pp. 136. 